\title{
PERENCANAAN SKENARIO DALAM PENGEMBANGAN BISNIS KULINER HALAL DI PULAU LOMBOK - NUSA TENGGARA BARAT
}

\author{
Dewi Rispawati ${ }^{1}$, Vidya Yanti Utami ${ }^{2}$ \\ ${ }^{1}$ Prodi Ilmu Administrasi Niaga, Sekolah Tinggi Ilmu Administrasi (STIA) Mataram, Indonesia. \\ E-mail:drispawati@yahoo.com \\ 2Prodi Ilmu Administrasi Negara, Sekolah Tinggi Ilmu Administrasi (STIA) Mataram, Indonesia. \\ E-mail:vidyautami88@gmail.com
}

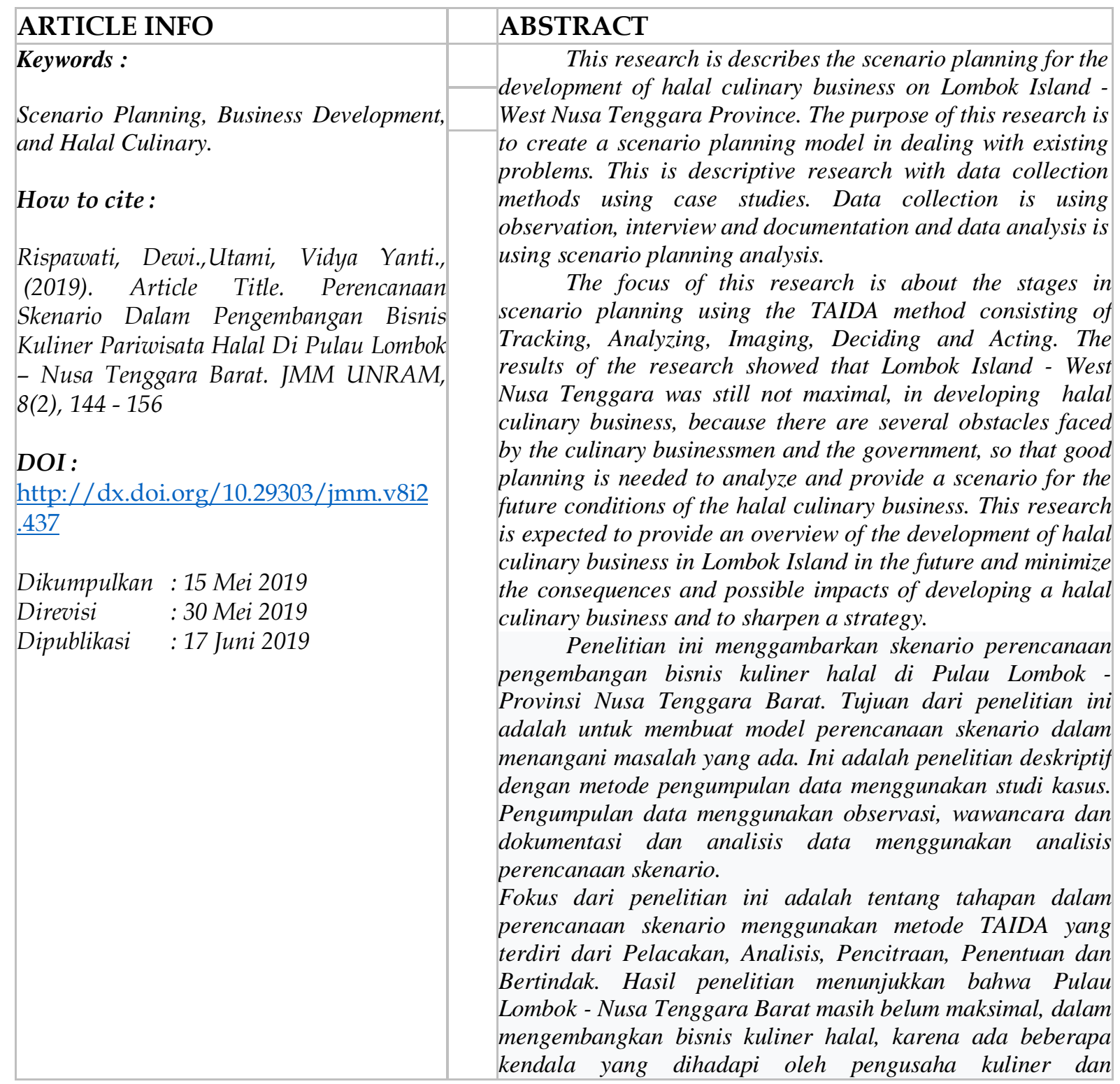




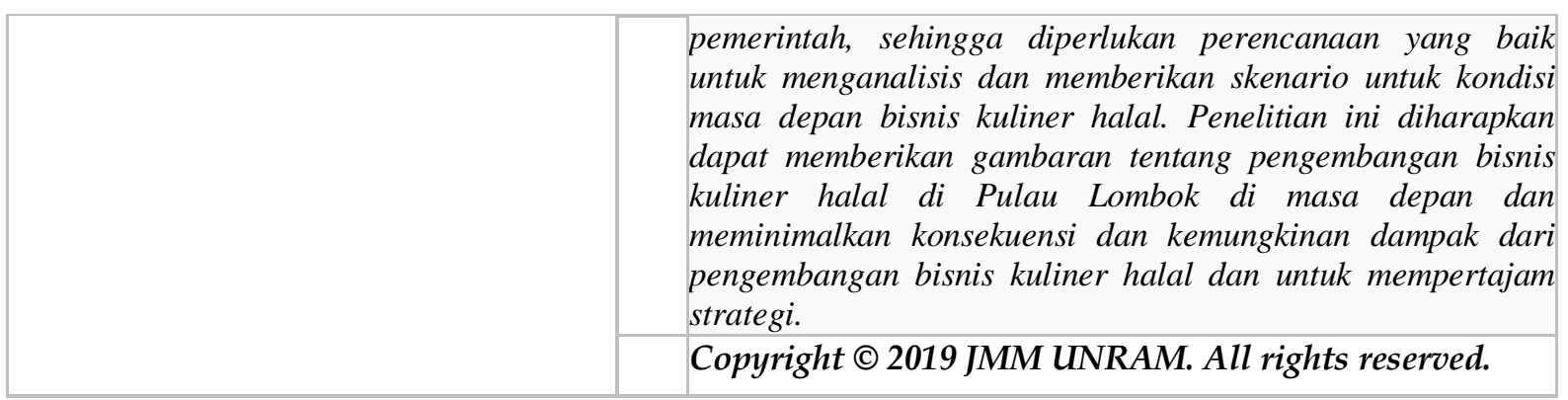

\section{PENDAHULUAN}

Provinsi Nusa Tenggara Barat tidak hanya memiliki pantai yang eksotik dan panorama alam yang memikat serta khazanah budaya adiluhung, tetapi juga kaya dengan berbagai kuliner khas daerah yang mengundang selara (mataram.antaranews.com 29/11/2017). Perkembangan sektor pariwisata yang cukup pesat di bumi "Seribu Masjid" ini, sejatinya telah mengangkat citra kuliner lokal. Demikian juga sebaliknya keberadaan kuliner khas daerah ini juga mendukung industri pelancongan di Nusa Tenggara Barat. Kuliner menjadi salah satu potensi pariwisata Pulau Lombok, bahkan banyak kuliner Lombok yang telah dikenal dan menjadi ciri khas, seperti Ayam Taliwang, Pelecing Kangkung dan Sate Rembiga. Sejatinya untuk mengembangkan industri pariwisata di Nusa Tenggara Barat tidak hanya mengandalkan tujuan wisata, tetapi kuliner juga harus dikembangkan sebagai suatu atraksi guna menarik minat wisatawan.

Selama dua kali berturut - turut di tahun 2015 dan tahun 2016 brand halal disematkan kepada daerah Lombok, Nusa Tenggara Barat (traveldetik.com 01/03/2019). Penghargaan itu yaitu World Best Halal Tourism Destination dan World Best Halal Honeymoon Destination pada tahun 2015 dan pada tahun 2016 Pulau Lombok kembali memenangkan tiga penghargaan yaitu World Best Halal Honeymoon Destination, World Best Halal Beach Resort dan World Best Halal Tourism Website. Penghargaan tersebut didapat dari negara Dubai pada ajang World Halal Tourism Award (WHTA). Kemudian pada tahun 2018, Provinsi Nusa Tenggara Barat (NTB) telah menjadi kiblat wisata halal yaitu dengan terpilihnya Provinsi Nusa Tenggara Barat sebagai Tujuan Wisata Halal Terfavorit dalam Anugerah Syariah Republika (ASR) Tahun 2018 (lombokinsider.com 11/11/2018).

Menurut data dari Global Muslim Travel Index (GMTI), diperkirakan pada tahun 2020 ada 159 juta wisatawan mancanegara muslim dan expenditure atau besarnya pengeluaran wisman muslim 220 miliar dolar. Jika kurs 14 ribu, maka 1 miliar dolar sama dengan 14 trilliun rupiah (traveldetik.com 01/03/2019). Selanjutnya dari laporan Global Islamic Economy Report 2016/2017, menyatakan bahwa pengeluaran muslim dunia dalam industri halal di sektor makanan dan gaya hidup (food and lifestyle sector expenditure) mencapai US\$1,9 triliun pada tahun 2015. Angka ini diperkirakan akan naik signifikan menjadi US\$ 3 triliun pada tahun 2021 (depok.pos.com 01/08/2019). Jika merujuk dari angka perhitungan itu, pemerintah dan pelaku bisnis mestinya lebih serius dengan segmen ini, karena melihat keuntungan besar dalam bisnis halal ini cukup menjanjikan.

Produk halal saat ini menjadi trend dan popularitas perkembangannya melesat, maka dari itu produk halal ini membuka peluang bisnis yang bagus khususnya di daerah yang memiliki mayoritas penduduk muslim. Ditambah lagi sasaran produksi halal tidak perlu khawatir kehilangan konsumen karena produk halal yang berkembang dan tumbuh dengan pesat juga karena adanya permintaan dari non muslim dan yang menarik perhatian non muslim juga banyak yang lebih memilih halal lifestlye terutama perihal makanan. Hal ini menunjukkan bahwa kesadaran konsumen akan produk halal yang 


\section{Jurnal Magister Manajemen Unram Vol. 8, No 2. Juni 2019}

NATIONALLY ACCREDITED JOURNAL - DECREE NO. 21/E/KPT/2018

terjamin lebih aman, sehat dan tidak perlu diragukan lagi untuk dikonsumsi, karena telah terbukti bahwa makanan yang telah tersertifikasi halal sudah pasti sehat.

Dengan pemberian sertifikat halal ini memberikan jaminan para tamu bahwa apa yang mereka konsumsi di sebuah restoran dan rumah makan berbahan baku halal harus benar -benar halal. Menurut Pasal 1 angka 10 Undang-Undang Nomor 33 Tahun 2014 tentang Jaminan Produk Halal, sertifikat halal adalah pengakuan kehalalan suatu produk yang dikeluarkan oleh Badan Penyelenggara Jaminan Produk Halal (BPJPH) berdasarkan fatwa tertulis yang dikeluarkan oleh Majelis Ulama Indonesia. Jika melihat Prosentase populasi 2010-2050 pertumbuhan agama islam diproyeksikan mencapai 73\% (The Future of World Religions \& PEW Research Center). Dari data tersebut menggambarkan peluang bisnis yang besar dan menguntungkan. Banyak negara yang menyambut peluang bisnis emas ini, bahkan dari beberapa negara yang penduduknya non muslim seperti Thailand, Korea dan juga Jepang menggencarkan standarisasi produk guna mendapatkan label halal.

Pulau Lombok merupakan salah satu daerah yang mempunyai potensi besar dalam mengembangkan bisnis kuliner halal. Hal ini juga sejalan dengan branding wisata halal yang sedang dijalankan Pulau Lombok yang ditandai dengan adanya Peraturan Daerah Provinsi Nusa Tenggara Barat Nomor 02 Tahun 2016 tentang Pariwisata Halal. Akan tetapi bisnis kuliner halal di Pulau Lombok saat ini masih belum berkembang dengan maksimal atau dengan kata lain masih berjalan stagnan. Masih terdapat beberapa kendala dan permasalahan yang ditemui dalam pengembangan bisnis kuliner halal baik dalam bentuk UMKM, restaurant/rumah makan dan usaha - usaha penyedia makanan yang belum bersertifikat halal. Hal ini salah satunya dikarenakan pelaku usaha/bisnis kuliner di Pulau Lombok belum menganggap adanya sertifikat halal sebagai penunjang penting dalam bisnis mereka. Padahal industri halal saat ini telah menjadi trend global di dunia. Disamping itu, dukungan pemerintah juga sangat dibutuhkan untuk memajukan bisnis kuliner halal yang ada di Pulau Lombok.

Melihat kenyataan diatas, bisnis kuliner halal di Lombok sangat memerlukan perencanaan disertai kebijakan/strategi yang tepat sasaran agar potensi yang dimiliki bisa dikembangkan secara optimal. Skenario perencanaan dapat dijadikan sebagai alat untuk memberikan gambaran-gambaran ketidakpastian di masa depan dan memberikan alternatif strategi (Lindgren dan Bandhold, 2003: 21). Mengingat masa depan bagi pebisnis adalah sebuah ketidakpastian dan harapan. Sangat penting bagi para pebisnis untuk mengetahui apa yang akan terjadi pada 5 bahkan 10 tahun ke depan sehingga bisa menyiapkan strategi apa yang akan digunakan. Scenario planning mencoba melihat secara berbeda yaitu melihat sesuatu dengan keseluruhan dari berbagai sudut. Dengan persiapan berbagai skenario dalam perencanaan, sehingga dapat lebih fleksibel dan tetap fokus dalam mengimplementasikan rencana bisnis yang efektif. "Don't forecast the future, but anticipate" dalam scenario planning harus selalu memerhatikan ketidakpastian baik dari internal maupun eksternal, lalu mencari langkah antisipasi dengan mengeluarkan kebijakan/strategi. Oleh karena itu, penulis ingin mengetahui bagaimana perencanaan skenario pengembangan bisnis kuliner halal di Pulau Lombok, Nusa Tenggara Barat.

\section{KAJIAN TEORITIS}

\subsection{Perencanaan Skenario}

Sebuah perencanaan skenario meupakan salah satu alternatif untuk menjalankan sebuah perencanaan. Perencanaan skenario juga merupakan sebuah gambaran tentang masa depan. Menurut Schwartz (dikutip dalam Lindgren 2003:21) perencanaan skenario adalah sebuah alat atau langkah untuk menyampaikan sebuah persepsi tentang gambaran 


\section{Jurnal Magister Manajemen Unram Vol. 8, No 2. Juni 2019}

NATIONALLY ACCREDITED JOURNAL - DECREE NO. 21/E/KPT/2018

berbagai kemungkinan (keadaan) yang dapat terjadi di masa yang akan datang. Metode yang digunakan dalam perencanaan skenario ini adalah metode TAIDA. Metode TAIDA dalam Perencanaan Skenario Menurut Lindgren and Baldhood (2003:47) adalah Method for Scenario Planning, metode ini merupakan langkah - langkah untuk menyusun suatu perencanaan skenario. TAIDA merupakan singkatan dari Tracking, Analyzing, Imaging, Deciding, and Acting.

a. Tracking (Pelacakan)

Tracking merupakan tahap awal dari TAIDA, dalam tracking dilakukan pelusuran terhadap kejadian yang pernah terjadi.

b. Analyzing (Menganalisis)

Tahap Analyzing dilakukan untuk menganalisis perencanaan terburuk dan terbaik terhadap dampak yang ditimbulkan.

Imaging (Penggambaran)

Kemudian setelah melakukan tahapan tracking dan analyzing, tahap selanjutnya adalah Imaging. Dalam tahap ini menciptakan visi.

c. Deciding (Memutuskan Kebijakan)

Memutuskan adalah fase dimana segala diputuskan secara bersama-sama. Hal ini menjabarkan misi untuk membuat kebijakan.

d. Acting (Bertindak/ Tindakan)

Tahapan ini merupakan implementasi strategi yang telah diintegrasikan oleh perencanaan sebelumnya.

\subsection{Pengertian Bisnis}

Menurut Alma, 1997:1 bisnis diartikan semua kegiatan yang mencakup menyediakan barang dan jasa yang diperlukan atau diinginkan oleh orang, dengan maksud menyediakan barang dan jasa untuk tujuan mencari keuntungan. Kegiatan bisnis mencari keuntungan ini dilakukan oleh usaha perseorangan, persekutuan atau kerjasama untuk memenuhi kebutuhan masyarakat. Hughes dan Kapoor dalam Alma, 1999: 21 bisnis ialah suatu kegiatan usaha individu yang terorganisasi untuk menghasilkan dan menjual barang dan jasa guna mendapatkan keuntungan dalam memenuhi kebutuhan masyarakat. Menurut Brown dan Petrello dalam Alma, 1999:21 bisnis ialah suatu lembaga yang menghasilkan barang dan jasa ynag dibutuhkan oleh masyarakat. Apabila kebutuhan masyarakat meningkat, maka lembaga bisnis pun akan meningkat pula perkembangannya untuk memenuhi kebutuhan tersebut, sampai memperoleh laba. Bisnis adalah usaha untuk memenuhi kebutuhan manusia, organisasi ataupun masyarakat luas (Gitosudarmo, 2001:2). Manusia bisnis (Businessman) akan selalu melihat adanya kebutuhan masyarakat dan kemudian mencoba untuk melayaninya secara baik sehingga masyarakat menjadi puas dan senang karenanya. Dari kepuasan masyarakat itulah si pengusaha akan mendapatkan keuntungan dan kemudian keuntungan tersebut akan digunakan untuk mengembangkan bisnis atau usahanya agar menjadi lebih luas lagi bagi masyarakat yang lebih luas lagi ataupun membuka bisnis baru bagi kebutuhan masyarakat yang lain lagi.

Tujuan utama dari bisnis ialah untuk memenuhi kebutuhan dan keinginan (needs and wants) manusia. Tujuan lain dari bisnis ialah memperoleh keuntungan, sehingga mereka berani memikul resiko menanam modal dalam kegiatan bisnis, dan ada pula bisnis yang tidak mengejar keuntungan, namun mereka perlu bantuan guna menjaga kelangsungan kegiatan bisnisnya (Alma,1999:23). Kegiatan orang bisnis adalah melakukan bisnis sebaik mungkin untuk mendapat keuntungan, maka yang menjadi pusat perhatian orang bisnis adalah bagaimana memproduksi, mengedarkan, menjual, dan membeli barang dengan 
memperoleh keuntungan (Keraf, 2012: 56). Singkatnya, sasaran dan tujuan, bahkan tujuan satu - satunya, dari bisnis adalah mendatangkan keuntungan sebesar - besarnya.

Kegiatan bisnis pada hakikatnya adalah merupakan kegiatan yang berusaha untuk memenuhi kebutuhan masyarakat (Gitosudarmo, 2001:2). Kegiatan bisnis digolongkan menjadi dua macam yaitu ada kegiatan bisnis yang dilakukan dengan tujuan untuk mencari laba atau keuntungan, tetapi juga terdapat adanya kegiatan bisnis yang tidak bertujuan untuk mencari keuntungan melainkan semata - mata ingin melayani kebutuhan masyarakat umum. Bisnis meliputi semua aspek kegiatan untuk menyalurkan barang barang melalui saluran produktif, dari membeli bahan mentah sampai menjual barang jadi (Swastha dan Sukotjo, 2002:11). Business plan adalah dokumen tertulis yang disiapkan oleh wirausaha yang menggambarkan semua unsur - unsur yang relevan baik internal maupun eksternal mengenai perusahaan untuk memulai sewaktu usaha (Hisrich-Peters dalam Alma, 2008:219). Menurut Megginson dalam Alma, 2008: 220, Business plan adalah suatu rencana tertulis yang memuat misi dan tujuan bisnis, cara kerja dan rincian keuangan/permodalan susunan para pemilik dan manajemen dan bagaimana cara mencapai tujuan bisnisnya.

\subsection{Pengembangan Bisnis/Usaha}

Pengembangan bisnis/usaha adalah tugas dan proses persiapan analitis tentang peluang pertumbuhan potensial, dukungan dan pemantauan pelaksanaan peluang pertumbuhan bisnis, tetapi tidak termasuk keputusan strategis dan implementasi dari peluang pertumbuhan bisnis. Beberapa definisi pengembangan bisnis/usaha menurut ahli (Haris Fadilah, 2012) yaitu :

\begin{tabular}{|c|l|l|}
\hline No. & \multicolumn{1}{|c|}{ Pendapat Ahli } & \multicolumn{1}{|c|}{ Definisi Pengembangan Bisnis/Usaha } \\
\hline 1. & Mahmud Mach Foedz & $\begin{array}{l}\text { Perkembangan usaha adalah perdagangan yang } \\
\text { dilakukan oleh sekelompok orang yang terorganisasi } \\
\text { untuk mendapatkan laba dengan memproduksi dan } \\
\text { menjual barang atau jasa untuk memenuhi kebutuhan } \\
\text { konsumen. }\end{array}$ \\
\hline 2. & Brown dan Petrello & $\begin{array}{l}\text { Pengembangan usaha adalah usaha suatu lembaga yang } \\
\text { menghasilkan barang dan jasa yang dibutuhkan } \\
\text { masyarakat. Apabila kebutuhan masyarakat meningkat, } \\
\text { maka lembaga bisnis pun akan meningkat pula } \\
\text { perkembangannya untuk memenuhi kebutuhan } \\
\text { tersebut, disamping memperoleh laba. }\end{array}$ \\
\hline 3. & Steinford & $\begin{array}{l}\text { Pengembangan usaha adalah aktivitas yang } \\
\text { menyediakan barang atau jasa yang diperlukan oleh } \\
\text { konsumen yang memiliki badan usaha, maupun } \\
\text { perorangan yang tidak memiliki badan hukum maupun } \\
\text { badan usaha seperti, pedagang kaki lima yang tidak } \\
\text { memiliki surat izin ditempat usaha. }\end{array}$ \\
\hline 4. & Hughes dan Kapoor & $\begin{array}{l}\text { Pengembangan usaha ialah kegiatan usaha individu } \\
\text { yang terorganisasi untuk menghasilkan dan menjual } \\
\text { barang jasa guna mendapatkan keuntungan. }\end{array}$ \\
\hline 5. & Mussleman dan Jackson & $\begin{array}{l}\text { Pengembangan usaha adalah suatu aktivitas yang } \\
\text { memenuhi kebutuhan dan keinginan ekonomis } \\
\text { masyarakat dan perusahaan diorgranisasikan untuk } \\
\text { terlibat dalam aktivitas tersebut. }\end{array}$ \\
\hline
\end{tabular}




\begin{tabular}{|c|l|l|}
\hline 6. & Allan Affuah & $\begin{array}{l}\text { Pengembangan usaha merupakan sekumpulan aktivitas } \\
\text { yang dilakukan untuk menciptakan dengan cara } \\
\text { mengembangkan dan mentransformasikan berbagai } \\
\text { sumber daya barang atau jasa yang dinginkan } \\
\text { knsumen. }\end{array}$ \\
\hline 7. & Glos, Steade dan Lawry & $\begin{array}{l}\text { Pengembangan usaha adalah jumlah seluruh kegiatan } \\
\text { yang diorganisasikan oleh orang - orang yang } \\
\text { berkecimpung dalam bidang perniagaan dan industri } \\
\text { yang menyediakan barang dan jasa untuk kebutuhan } \\
\text { mempertahankan dan memperbaiki standar serta } \\
\text { kualitas hidup mereka. }\end{array}$ \\
\hline 8. & Huat T Chwee & $\begin{array}{l}\text { Ada dua pengertian pengembangan usaha, yaitu: } \\
\text { pengembangan usaha dalam arti yang luas adalah } \\
\text { istilah umum menggambarkan semua aktivitas dan } \\
\text { institusi yang memproduksi barang dan jasa dalam } \\
\text { kehidupan sehari - hari. }\end{array}$ \\
\hline
\end{tabular}

Jadi pengembangan pengembangan usaha/bisnis yang besar terutama di bidang teknologi industri, mengacu pada pengaturan dan mengelola hubungan strategis dan aliansi dengan yang lain. Dalam hal ini perusahaan dapat memanfaatkan satu sama lain keahlian, teknologi atau kekayaan intelektual untuk memperluas kapasitas mereka dalam mengidentifikasi, meneliti, menganalisa dan membawa ke pasar bisnis baru dan produk baru, pengembangan usaha/bisnis berfokus pada implementasi dari rencana bisnis strategis melalui ekuitas pembiayaan, akuisisi/divestasi teknologi, produk dan lain - lain (Wikipedia Indonesia, 23/1/2017).

\subsection{Pengertian Kuliner}

Pengertian kuliner secara umum adalah kegiatan yang berhubungan dengan memasak atau aktivitas memasak. Kuliner juga dapat dimaknai sebagai hasil olahan yang berupa masakan lauk-pauk, panganan maupun minuman (https://www.kanalinfo.web.id, 2/1/2019). Kuliner tidak terlepas dari kegiatan masak - memasak yang erat kaitannya dengan konsumsi makanan sehari - hari. Kata kuliner merupakan unsur serapan bahasa inggris yaitu culinary yang berarti berhubungan dengan masak - memasak atau aktivitas memasak. Sedangkan orang yang bekerja di bidang kuliner disebut koki atau chef. Ada juga wisata kuliner yaitu wisata yang bertujuan untuk mencoba menikmati hasil masakan di tempat wisata tersebut. Wisata kuliner merupakan perpaduan menikmati suatu makanan sambil menikmati suasana jalan - jalan, bersantai atau sedang berlibur, sehingga memanfaatkan waktu ke tempat - tempat yang menyediakan makanan khas (https://www.kanalinfo.web.id, 2/1/2019). Saat ini kuliner sudah merupakan sebuah gaya hidup yang tidak dapat dipisahkan dari kehidupan sehari - hari karena makanan adalah sebuah kebutuhan sehari - hari. Semua itu, membutuhkan cara pengolahan makanan yang enak.

\subsection{Pengertian Halal}

Halal adalah segala objek atau kegiatan yang diizinkan untuk digunakan atau dilaksanakan, dalam agama Islam. Istilah ini dalam kosakata sehari - hari lebih sering digunakan untuk menunjukkan makanan dan minuman yang diizinkan untuk dikonsumsi menurut Islam, menurut jenis makanan dan cara memperolehnya (https://id.m.wikipedia.org/wiki/Halal, 2019). Halal adalah segala sesuatu yang diperbolehkan oleh syariat untuk dikonsumsi terutama, dalam hal makanan dan minuman 


\section{Jurnal Magister Manajemen Unram Vol. 8, No 2. Juni 2019}

NATIONALLY ACCREDITED JOURNAL - DECREE NO. 21/E/KPT/2018

(https://m.republika.co.id, 10/8/2014). Di Indonesia, sertifikasi kehalalan produk-produk pangan dan minuman ditangani oleh Majelis Ulama Indonesia. Halal cara pengolahnnya yaitu, makanan yang semula halal dan akan menjadi haram apabila cara pengolahannya tidak sesuai dengan syariat agama. Kriteria halal yaitu (https://m.republika.co.id, 10/8/2014) :

1. Halal zatnya, makanan yang halal menurut zatnya adalah makanan yang dari dasarnya halal untuk dikonsumsi dan telah ditetapkan kehalalannya dalam $\mathrm{Al}$ Qur'an dan hadis.

2. Halal cara memperolehnya, yaitu makanan yang diperoleh dengan cara yang baik dan sah. Makanan akan menjadi haram apabila cara memperolehnya dengan jalan yang batil karena itu bisa merugikan orang lain dan dilarang oleh syariat.

3. Halal cara pengolahannya, yaitu makanan yang semula halal dan akan menjadi haram apabila cara pengolahnnya tidak sesuai dengan syariat agama. Banyak sekali makanan yang asalnya halal, tetapi karena pengolahannya yang tidak benar menyebabkan makanan itu menjadi haram.

\section{METODE PENELITIAN}

Jenis penelitian yang digunakan dalam penelitian ini adalah deskriptif di mana tujuannya penelitian ini, untuk mengetahui dan mendeskripsikan Perencanaan Scenario dalam pengembangan bisnis kuliner halal di Pulau Lombok - Nusa Tenggara Barat. Tujuan dari penelitian deskriptif ini adalah membuat deskripsi, gambaran atau lukisan secara sistematis, faktual dan akurat mengenai fakta - fakta, sifat serta hubungan antar fenomena yang diselidiki. Lokasi penelitian dilakukan pada bisnis kuliner yang ada di Pulau Lombok - Nusa Tenggara Barat. Metode pengumpulan data dalam penelitian ini adalah metode kasus (studi kasus). Dalam penelitian ini dilakukan kajian mengenai hal - hal yang berkaitan dengan perkembangan bisnis kuliner halal di Pulau Lombok - Nusa Tenggara Barat.

Teknik Pengumpulan Data dalam penelitian ini antara lain: (a) Teknik Observasi langsung terhadap obyek penelitian, dengan melakukan pengamatan secara langsung ke objek bisnis kuliner yang ada di Pulau Lombok - Nusa Tenggara Barat disertai dengan pencatatan secara sistematis terhadap hal - hal yang diselidiki guna memperoleh data yang diperlukan dalam penelitian, (b.) Teknik Wawancara yaitu dengan mengadakan tanya jawab langsung dengan pihak - pihak yang berwenang memberikan informasi dan data - data mengenai hal - hal yang berhubungan dengan obyek yang diteliti, ( c.)

Dokumentasi yaitu cara pengumpulan data dan telaah pustaka di mana dokumen dokumen yang dianggap menunjang dan relevan dengan permasalahan yang diteliti baik berupa literature dan laporan, dengan mencantumkan gambar dan bukti dokumentasi yang diperoleh pada objek penelitian. Alat pengumpulan data dalam penelitian ini yaitu berupa daftar pertanyaan yang disusun oleh peneliti untuk mengumpulkan data dan informasi.

Jenis data yang digunakan dalam penelitian ini adalah: data kualitatif yaitu data yang tidak dapat diukur secara langsung atau tidak berbentuk angka - angka hanya berupa penjelasan atau keterangan - keterangan. Sumber data yang digunakan dalam penelitian ini adalah: (1.) Data Primer adalah data yang diperoleh langsung dari obyek penelitian yang bersumber dari pihak pimpinan atau karyawan pada Kantor Dinas Pariwisata yang telah diberikan wewenang untuk memberikan data dan informasi yang diperlukan dalam penelitian, (2.) Data Sekunder merupakan data yang diperoleh dari objek penelitian yang ada kaitannya dengan masalah yang diteliti. Dalam hal ini data diperoleh dari instansi lain 


\section{Jurnal Magister Manajemen Unram Vol. 8, No 2. Juni 2019 NATIONALLY ACCREDITED JOURNAL - DECREE NO. 21/E/KPT/2018}

seperti Perpustakaan, dan bahan bacaan maupun literatur yang berkaitan dengan penelitian.

Menentukan tahapan - tahapan kebijakan strategi yang dapat diterapkan untuk pengembangan bisnis kuliner halal di Pulau Lombok - Nusa Tenggara Barat dengan menggunakan analisis Perencanaan Scenario. Analisis Perencanaan Scenario adalah salah satu alternatif untuk menjalankan sebuah perencanaan. Fokus dari penelitian ini yaitu mengenai tahapan dalam perencanaan skenario yang menggunakan metode TAIDA, yang terdiri dari Tracking, Analyzing, Imaging, Deciding and Acting. Perencanaan scenario juga merupakan sebuah gambaran tentang masa depan. Menurut Schwartz dalam Lindgren 2003:21, perencanaan scenario dalah sebuah alat atau langkah untuk menyampaikan sebuah persepsi tentang gambaran berbagai kemungkinan (keadaan) yang dapat terjadi di masa yang akan datang.

\section{HASIL DAN PEMBAHASAN}

\subsection{Perencanaan Skenario dalam Pengembangan Bisnis Kuliner Halal di Pulau Lombok, Provinsi Nusa Tenggara Barat}

Meskipun Pulau Lombok memiliki potensi besar dalam mengembangkan bisnis kuliner halal seperti yang telah dipaparkan di atas, namun kondisi bisnis kuliner halal di Pulau Lombok masih belum maksimal. Masih terdapat banyak kendala yang ditemui dalam pengembangannya. Untuk itulah maka dibutuhkan perencanaan disertai strategi yang tepat sasaran melalui perencanaan skenario. Dengan adanya perencanaan skenario ini diharapkan dapat membantu pemerintah, pihak pengusaha, masyarakat dan berbagai pihak terkait dalam menyusun startegi - strategi terkait pengembangan bisnis kuliner halal dengan melihat kemungkinan - kemungkinan yang terjadi sehingga memiliki gambaran yang lebih jelas kedepannya. Adapun untuk melakukan perencanaan skenario terhadap pengembangan bisnis kuliner di Pulau Lombok, maka dibutuhkan beberapa langkah yang ada dalam metode TAIDA (Lindgren dan Bandhold, 2003: 48) seperti Tracking, Analyzing, Imaging, Deciding, and Acting.

\subsubsection{Tracking}

Dalam membangun skenario yang tepat, maka langkah pertama yang harus dilakukan adalah mengidentifikasi trends dan issues. Pengidentifikasian ini dilakukan untuk memahami masalah yang diteliti. Dalam tahapan ini menemukan dua masalah utama yaitu Pihak Pengusaha dan Peran Pemerintah.

\subsubsection{Analyzing}

Tahapan mengalisis perubahan dan membuat scenario. Menganalisis konsekuensi yang dapat muncul akibat keberadaan tantangan dan peluang. Pada tahap ini logika scenario mulai dikembangkan. 


\section{Jurnal Magister Manajemen Unram Vol. 8, No 2. Juni 2019 NATIONALLY ACCREDITED JOURNAL - DECREE NO. 21/E/KPT/2018}

Gambar 1. Matrix Skenario

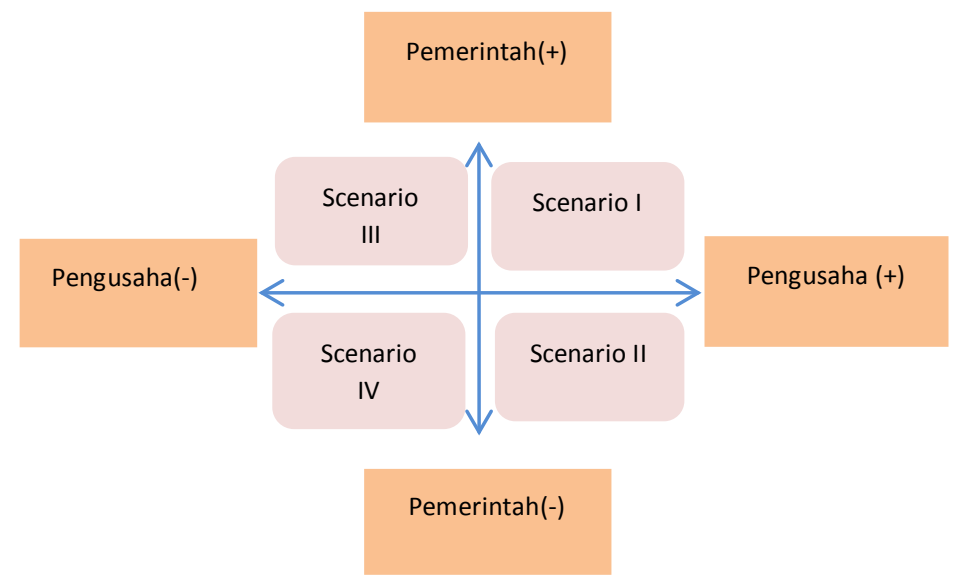

Sumber : Data Olahan Peneliti, 2019

\section{1) Skenario I, Pemerintah Memfasilitasi dan Pihak Pengusaha yang Mendukung}

Skenario I ini merupakan skenario optimis (terbaik), dimana faktor pihak pengusaha dan pemerintah mendukung pengembangan bisnis kuliner halal di Pulau Lombok. Skenario ini berdampak baik bagi pengembangan bisnis kuliner halal di Pulau Lombok, karena dengan support dan fasilitas yang disediakan pemerintah seperti dengan memberikan subsidi untuk pengurusan sertifkat halal sebesar Rp. 2 juta/UMKM meskipun dengan jumlah yang terbatas, kerjasama yang baik antar SKPD terkait seperti Dinas Koperasi Usaha Mikro Kecil dan Menengah, Dinas Kesehatan, Majelis Ulama Indonesia (MUI) Provinsi Nusa Tenggara Barat (NTB), Badan Pengawasan Obat dan Makanan (BPOM). Begitupun juga pihak pengusaha yang tidak enggan untuk segera mengurus sertifikasi halal bagi usaha - usaha mereka, sehingga berdampak pada meningkatnya jumlah wisatawan karena merasa aman ketika mengkonsumsi makanan yang telah bersertifikat halal. Dalam skenario ini juga pihak pengusaha melihat peluang besar yang menguntungkan jika mereka mempunyai sertifikat halal pada usaha kuliner mereka. Minat dan kesadaran pihak pengusaha untuk mensertifikasi halal bisnisnya setiap tahunnya semakin meningkat dalam upaya mendukung pariwisata halal yang sedang dikembangkan di Pulau Lombok. Upaya mewujudkan pengembangan bisnis kuliner halal tersebut juga tidak terlepas dari komitmen pemerintah dan pihak terkait untuk terus mengembangankan industri halal di berbagai aspek. Sehingga Pulau Lombok masih terus bisa bersaing dengan daerah lain yang juga menawarkan konsep halal. Pada akhirnya dalam skenario ini, Pulau Lombok bisa memaksimalkan berbagai potensi yang dimilikinya demi menyediakan kuliner halal kepada wisatawan, sehingga nantinya Pulau Lombok bisa mendapatkan penghargaan/predikat "best halal food" yang otomatis juga berdampak pada meningkatnya minat wisatawan muslim bahkan non muslim untuk berwisata ke Pulau Lombok.

\section{2) Skenario II, Pihak Pengusaha Mendukung dan Pemerintah tidak memfasilitasi dengan baik}

Pada skenario II, Pihak Pengusaha Mendukung dan Pemerintah tidak memfasilitasi dengan baik masih merupakan perencanaan skenario yang baik, karena masih bisa dikendalikan. Pemerintah dalam hal ini kurang maksimal dalam memberikan pelayanan dan memfasilitasi proses sertifikasi halal bagi restaurant, UMKM dan usaha - usaha kuliner yang mana terkendala pada dana operasional untuk survey/observasi dan kerjasama antar SKPD terkait dalam proses pemberian sertifikat halal, serta prosedur yang panjang. Dalam 
scenario II ini memiliki dampak negatif juga, tetapi tidak terlalu besar terhadap pengembangan bisnis kuliner halal di Pulau Lombok. Sebaliknya pada skenario ini, pihak pengusaha sudah mendukung dan sadar bahwa dengan mengurus label halal bagi usaha mereka, tentu akan sangat menguntungkan bagi usaha kuliner mereka. Namun, skenario ini masih bisa dibilang merupakan skenario yang baik karena masih bisa dikendalikan yaitu karena meskipun harus melewati prosedur yang panjang untuk memperoleh sertifikasi halal dan terbatasnya bantuan dana yang diberikan pemerintah untuk mengurus sertifikasi halal, namun pihak pengusaha berinisiatif untuk mengurus secara mandiri biaya pengurus sertifkat halal, tanpa harus menunggu bantuan dari APBD Nusa Tenggara Barat.

\section{3) Skenario III, Pemerintah Memfasilitasi dan Pihak Pengusaha tidak mendukung}

Dalam perencanaan scenario III seperti halnya jungkat - jungkit yang berat sebelah dan tidak imbang karena pihak pemerintah sudah mensupport dan memfasilitasi dengan baik dalam hal proses sertifikasi halal. Pemerintah dalam skenario ini, telah berusaha memberikan pelayanan yang mudah dan bantuan dana bagi pengusaha - pengusaha kuliner untuk mengurus sertifikat halal. Sebaliknya di sisi lain, pihak pengusaha masih kurang menganggap perlunya mengurus sertifikat halal bagi usaha mereka karena mereka menganggap makanan yang mereka sajikan sudah halal karena yang memasak adalah orang Islam dan tidak menggunakan bahan - bahan seperti Babi. Hal ini semacam "self claim" bagi usaha mereka. Jika dalam mengatasi perencanaan ini tidak bisa maksimal, maka hal ini bisa menjadi buruk meskipun pemerintah sudah memfasilitasi proses sertifikasi halal dengan baik, namun apalah artinya jika dari pihak pengusaha tidak mensupport dan enggan untuk mengurus sertifikasi halal bagi usaha - usaha mereka.

\section{4) Skenario IV, Pihak Pengusaha tidak mendukung dan Pihak Pemerintah tidak memfasilitasi dengan baik}

Skenario perencanaan IV ini, merupakan perencanaan yang terburuk terhadap dampaknya, baik terhadap pemerintah, pengusaha dan masyarakat. Dalam scenario ini, diprediksi bisnis kuliner halal di Pulau Lombok tidak berkembang dan stagnan. Slogan dan kebijakan terkait Halal di Pulau Lombok akan hilang dengan sendirinya. Terjadi kondisi dimana usaha - usaha restaurant, UMKM dan penyedia kuliner masih banyak yang tidak mempunyai sertifikat halal sehingga kebijakan pemerintah untuk membuat Pulau Lombok menjadi destinasi wisata halal tidak bisa benar - benar terwujud. Bahkan lebih dari itu terjadinya kondisi di mana bisnis kuliner halal tidak berkembang dan akan mengurangi minat wisatawan yang datang. Pihak pengusaha acuh tak acuh dalam mengurus sertifikat halal karena menganggap usaha mereka sudah halal, hanya karena yang memasak adalah orang islam dan tidak menggunakan bahan-bahan non halal, padahal definisi halal lebih dari itu. Sedangkan pemerintah tidak menganggap dan menangkap peluang industri halal ini dengan baik sehingga akan membuat Pulau Lombok semakin tertinggal dengan daerah lain yang juga menawarkan industri halal di daerahnya.

\subsubsection{Imaging}

Kendala dalam mengembangkan bisnis kuliner halal di Pulau Lombok dapat memberikan pengaruh yang cukup besar dalam keberlanjutan industri halal di Pulau Lombok dan membuat wisatawan ragu - ragu untuk mencoba kuliner di Pulau Lombok. Oleh karena itu dalam mengatasi kendala tersebut perlu visi yang komprehensif untuk mengatasi seluruh ketidakpastian terhadap pengembangan bisnis kuliner halal di Pulau Lombok.

Visi : Terwujudnya Ekonomi Syariah Secara Menyeluruh Di Pulau Lombok Yang Berdaya Saing Internasional. 


\section{Jurnal Magister Manajemen Unram Vol. 8, No 2. Juni 2019 NATIONALLY ACCREDITED JOURNAL - DECREE NO. 21/E/KPT/2018}

Visi tersebut sesuai dengan kondisi industri halal di Pulau Lombok yang ingin dicapai di masa sekarang dan di masa mendatang. Visi tersebut mendorong pemerintah di Pulau Lombok untuk terus berusaha agar branding halal ini bisa diterapkan dan berjalan dengan baik, tidak hanya sekedar slogan. Melihat ekonomi muslim yang tinggi dan halal/nilai Islam yang telah menjadi life style, maka industri halal ini perlu untuk terus dikembangkan. Bukan hanya akan membawa kebaikan bagi manusia namun hewan tumbuhan lingkungan akan merasakan manfaatnya.

\subsubsection{Deciding}

Meningkatkan kesadaran pihak pengusaha bisnis kuliner terkait besarnya peluang dalam industri halal dan segera mengurus sertifikat halal bagi usaha - usaha kuliner mereka, karena tidak ada ruginya jika mengurus, yang ada bisnis mereka semakin diminati oleh wisatawan muslim yang sedang berwisata ke pulau Lombok. Bahkan Pulau Lombok semakin diminati oleh wisatawan muslim karena telah menyediakan produk halal yang terjamin kualitasnya. Kebijakan tersebut dapat menjadi misi yang dapat mempengaruhi implememtasi dan program yang akan dijalankan terkait pengembangan industri halal di Pulau Lombok yang terus dijalankan di Pulau Lombok. Kemudian, tak lepas juga dari dukungan pemerintah yang memfasilitasi, yaitu dengan memberikan bantuan dana dalam mengurus sertifikat halal yang mana dianggarkan dari APBD Nusa Tenggara Barat, kemudian dengan mempermudah prosedur sertifikasi halal sehingga pihak pengusaha kuliner semakin bersemangat untuk mengurus sertifikat halal bagi usaha mereka.

\subsubsection{Acting}

Pada tahapan ini merupakan implementasi strategi dalam pengembangan bisnis kuliner halal di Pulau Lombok - Nusa Tenggara Barat antara lain sebagai berikut :

a) Meningkatkan sosialisasi terkait peluang besar dalam indutri halal khususnya dalam hal halal food atau bisnis kuliner halal yang sangat menjanjikan.

b) Sosialisasi lebih giat kepada pelaku usaha bisnis kuliner agar mereka sadar akan pentingnya mengurus sertifikasi halal bagi restaurant maupun rumah makan milik mereka.

c) Proses survey dan pemberian sertifikasi halal dalam bisnis kuliner dipermudah dan dipercepat dalam pengurusannya.

d) Kejelasan standart halal agar pihak pelaku usaha bisnis kuliner tidak kebingungan untuk mempersiapkan pengurusan sertifikat halal bagi restaurantnya.

e) Kerjasama yang baik antar SKPD terkait dalam melaksanakan proses penilaian suatu bisnis kuliner halal.

f) Membuat mapping daerah bisnis kuliner halal.

g) Meningkatkan sosialisasi kepada semua pihak pengusaha dan masyarakat untuk proaktif mensertifikasi kegiatan usaha industri halal yang diterbitkan oleh Majelis Ulama Indonesia (MUI) - Nusa Tenggara Barat.

h) Pemerintah daerah memberikan bantuan dana kepada para pelaku usaha bisnis kuliner untuk mengurus sertifikasi halal.

i) Badan Penyelenggara Jaminan Produk Halal (BPJPH) dapat bekerjasama yang baik antar SKPD di Provinsi Nusa Tenggara Barat dalam memberikan jaminan sertifikasi halal bagi para pelaku usaha bisnis kuliner. 


\section{Jurnal Magister Manajemen Unram Vol. 8, No 2. Juni 2019 NATIONALLY ACCREDITED JOURNAL - DECREE NO. 21/E/KPT/2018}

\section{KESIMPULAN}

Dari hasil pembahasan dapat ditarik kesimpulan bahwa terdapat empat alternatif skenario, namun terdapat skenario (gambaran) yang diperkirakan paling mendekati dengan keadaan bisnis kuliner halal di Pulau Lombok. Pada kisaran tahun 2019 - 2024 seknario III, yang paling mendekati yaitu menggambarkan bahwa bisnis kuliner yang sudah memiliki sertifikat halal masih belum maksimal. Hal ini dikarenakan pelaku usaha bisnis kuliner masih enggan mengurus sertifikat halal bagi usaha mereka. Persoalan yang juga muncul adalah karena belum siapnya pelaku bisnis kuliner dalam memenuhi kriteria agar produk produknya mendapat sertifikat halal. Ketidaksiapan juga muncul lantaran karena prosedur sertifikasi yang terlalu panjang dan berbelit - belit. Namun pada kondisi ini fasilitas yang diberikan oleh pemerintah sudah cukup baik, yaitu karena pemerintah sudah terus melakukan dan mengupayakan pembenahan dalam hal proses sertifikasi halal agar tidak terlalu panjang dan memberikan bantuan biaya untuk sertifikasi yang diperkirakan pihak pelaku usaha akan dikenakan biaya $10 \%$ dari biaya sertifikasi. Apalagi akan ada kewajiban sertifikasi halal bagi produk makanan, minuman, kosmetik, obat - obatan dan benda benda lain yang akan diberlakukan pada bulan Oktober tahun 2019 ini. Hal ini sesuai dengan amanat Undang - Undang Nomor 33 Tahun 2014 tentang Jaminan Produk Halal. Sehingga hal tersebut diprediksikan akan mempengaruhi pengembangan bisnis kuliner halal dan juga jumlah minat wisatawan yang datang di Pulau Lombok.

\section{DAFTAR PUSTAKA}

Alma, Buchari. (1997). Dasar-Dasar Bisnis Dan Pemasaran. Bandung : CV. Alfabeta.

Alma, Buchari. (1999). Pengantar Bisnis. Bandung : CV. Alfabeta.

Alma, Buchari. (2008). Kewirausahaan. Bandung: CV. Alfabeta.

Antara News NTB. (2017). Wisata Kuliner Dukung Pengembangan Pariwisata NTB. https://mataram.antaranews.com/berita/35635/wisata-kuliner

dukung pengembangan pariwisata-ntb. Diakses 20 April 2019.

Depok Pos. (2018). Halal is My Life Style: Peluang dan Tantangan Bisnis Kuliner Halal. https:/ / www.depokpos.com/arsip/2018/08/halal-is-my-lifestyle-peluang-dan tantangan-bisnis-kuliner-halal/. Diakses 21 April 2019.

Detik Travel. (2019). Apa Lombok Sudah Jadi Destinasi Wisata Halal yang Sebenarya. https://travel.detik.com/travel-news/d-4449893/apa-lombok-sudah-jadi-destinasiwisata-halal-yang-sebenarnya. Diakses 20 April 2019.

Fadilah, Haris. (2012). Pengembangan Usaha: Wordpress.com; Online 10 April 2013.

Gitosudarmo, Indriyo. (2001). Pengantar Bisnis. Yogyakarta: BPFE-Yogyakarta.

Gitosudarmo, Indriyo. (2001). Manajemen Strategis. Yogyakarta: BPFE-Yogyakarta.

Kanal Informasi. (2019). Pengertian Kuliner. https://www.kanalinfo.web.id/pengertiankuliner, Diakses 21 April 2019.

Keraf, Sonny. A (2012). Etika Bisnis Tuntutan dan Relevansinya. Yogyakarta: Kanisius.

Ligdgren, Mats; Bandhold, Hans. (2003). Scenario Planning: The Link Between Future and Strategy. Palgrave Machmillan: Hampshire.

Lombok Insider. (2018). Keren NTB Terpilih Sebagai Destinasi Halal Terfavorit 2018. https://lombokinsider.com/destination-news/kerenntb-terpilih-sebagai-destinasihalal-terfavorit-2018/. Diakses 21 April 2019.

Peraturan Daerah Provinsi Nusa Tenggara Barat Nomor 02 Tahun 2016 tentang Pariwisata Halal. 
Republika. (2014). Definisi Halal. https://m.republika.co.id/Pengertian halal, Diakses 20 April 2019.

Swastha, Basu dan Sukotjo W Ibnu.(2002).Pengantar Bisnis Modern. Yogyakarta: Liberty Yogyakarta.

Undang - Undang Nomor 33 Tahun 2014 Tentang Jaminan Produk Halal.

Wikipedia Indonesia. (2017). Pengertian Pengembangan Bisnis Menurut Para Ahli. https:/ / pbisnis07.blogspot.com/2017/01/pengertian-pengembangan-bisnismenurut.html. Diakses 21 April 2019.

Wikipedia. (2019). Halal (Hal Yang Diizinkan Dalam Islam). https://id.m.wikipedia.org/w iki/Halal, Diakses 20 April 2019. 